\title{
The Demand of Voluntourism in a Developing Country
}

\author{
Pannee Suanpang1, Nawanun Srisuksai ${ }^{2}$, Panicha Tansutichon ${ }^{2}$ \\ ${ }^{1}$ Information Technology Department, Faculty of Science \& Technology, Suan Dusit University, Bangkok, Thailand \\ ${ }^{2}$ Suan Dusit University, Bangkok, Thailand \\ Email: dtechpannee@yahoo.com, fanggy.s@gmail.com, japanicha2@gmail.com
}

How to cite this paper: Suanpang, P., Srisuksai, N. and Tansutichon, P. (2018) The Demand of Voluntourism in a Developing Country. Journal of Service Science and Management, 11, 333-342. https://doi.org/10.4236/jssm.2018.113023

Received: April 13, 2018

Accepted: June 22, 2018

Published: June 25, 2018

Copyright ( 92018 by authors and Scientific Research Publishing Inc. This work is licensed under the Creative Commons Attribution International License (CC BY 4.0).

http://creativecommons.org/licenses/by/4.0/

(c) (i) Open Access

\begin{abstract}
"Voluntourism" or volunteer tourism is a new dimension of tourism that implies that tourists offer their services or affords to change some aspect of society for a better place to live and receive value from their tourism experience. The objective of this paper is to analyse the demand of volunteer tourism in a developing country case study in the Northeast of Thailand. This study is a quantitative study and data were collected from surveying volunteer tourists. The results found that there were four factors that affect the demand for volunteer tourism including motivation, attitude, expectation and need. The statistical significances of the goodness of fit indices are Chi-Square $=5.32, \mathrm{df}=$ 2, p-value 0.06978, RMSEA $=0.069$.
\end{abstract}

\section{Keywords}

Voluntourism, Volunteer Tourism, Demand Analysis, Factor Analysis, Confirmatory Factor Analysis (CFA), Developing Country, Thailand

\section{Introduction}

"Voluntourism" or volunteer tourism has its roots in "volunteerism" which implies that individuals offer their services or affords to change some aspect of society for a better place to live [1]. The concept of volunteer tourism comprises both volunteerism and tourism which began as a niche form of tourism. Currently it can be discovered in virtually every industry and is becoming popular as mass tourism [2] [3] [4]. Singh and Singh [5] [6] [7] define volunteer tourism “... as being more of a conscientious practice of righteous tourism-one that comes closest to utopia. At best, it may be regarded as an altruistic form of tourism, which has the capacity to uphold the highest ideals, intrinsically interwoven in the tourism phenomenon". Besides, Wearing [4] [5] defines volunteer tourists 
as "...for various reasons volunteer in an organized way to undertake a holiday that might involve aiding or alleviating the material poverty of some groups in society, the restoration of certain environments or research into aspects of society or environment."

The volunteer tourism categories (Figure 1) [1] which as a form of "alternative tourism" offer an alternative direction where the objective is that the tourists help the local community. Volunteer tourism is linked to "social tourism" [1] [8] "charity tourism", "moral tourism" [1] [9] and "serious tourism" [1] [10] that link the volunteer tourist to working on local projects in the community [1] that can be experienced with cultural tourism as well.

The number of the research studies on volunteer tourism is growing especially in many recent studies in terms of market, its scope and the motivation of participants [5]. The volunteer tourism sector has occurred since 1990 and it is estimated that 1.6 million people worldwide participate in volunteer tourism projects annually and that volunteer tourists spend between $£ 832$ million and $£ 1.3$ billion per year [11] [12]. Earthwatch who has been involved with volunteer projects between 1971-2008 found that upwards of 90,000 volunteers in 1350 projects across 120 countries, contribute US $\$ 67$ million and 11 million hours to scientific fieldwork [11] [12] [13]. Furthermore, volunteer tourism is found on the World Wide Web. A Google search of the word "volunteer tourism" in April 2008 returned 230,000 hits, but in August 2017 found 6,170,000 hits which included published research, volunteer tourism operators and NGOs, and the popular press [12] [14].

The situation of volunteer tourism in Thailand is growing and becoming more popular especially in "Gap Year" or teenagers who wants to travel and work as volunteers in Thailand, undertaking many activities such as teaching and childcare in schools, building houses, looking after elephants, and health care for local people. According to Kontogeorgopoulous [15] who has been studying "Finding oneself while discovering others. An existential perspective on volunteer tourism in Thailand" found that the volunteer tourism experience is driven by a desire for existential authenticity in both its intrapersonal and interpersonal varieties, and that working with children facilitates existentially authentic outcomes for

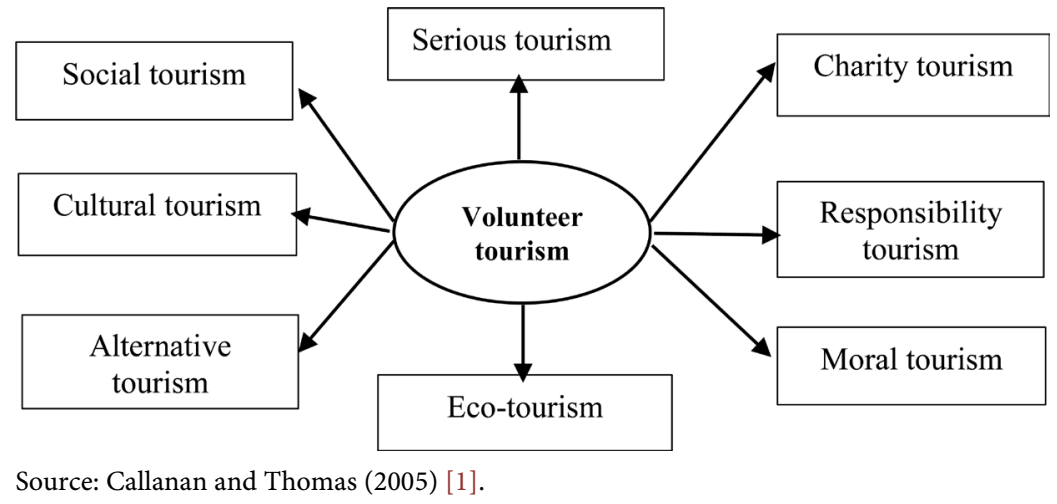

Figure 1. Categorising of volunteer tourism. 
volunteers.

This paper is part of a research project "The voluntourism development in Sanuk group (Sakon Nakhon, Nakon Phanom, Mukdahan provinces) (2016) [16] [17]. This paper focuses on the volunteer tourists" attitude and needs in Thailand (Figure 2).

The objective of this paper is to analyse the demand of volunteer tourism in a developing country in case study in the Northeast of Thailand. The research study is the area of Sanuk province (Sakon Nakhon, Nakon Phanom, Mukdahan) (Figure 3) because this area requires volunteer tourism to develop the local community. The tourism income is very low [16] [17] therefore, volunteer

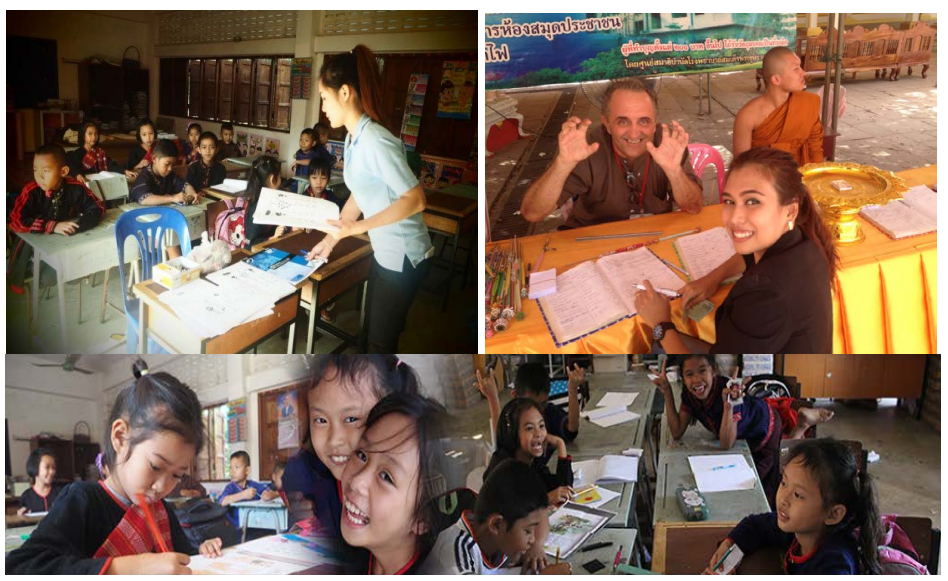

Source: Suanpang (2016) [16] [17].

Figure 2. Volunteer tourism in a developing country, a case study in Thailand.

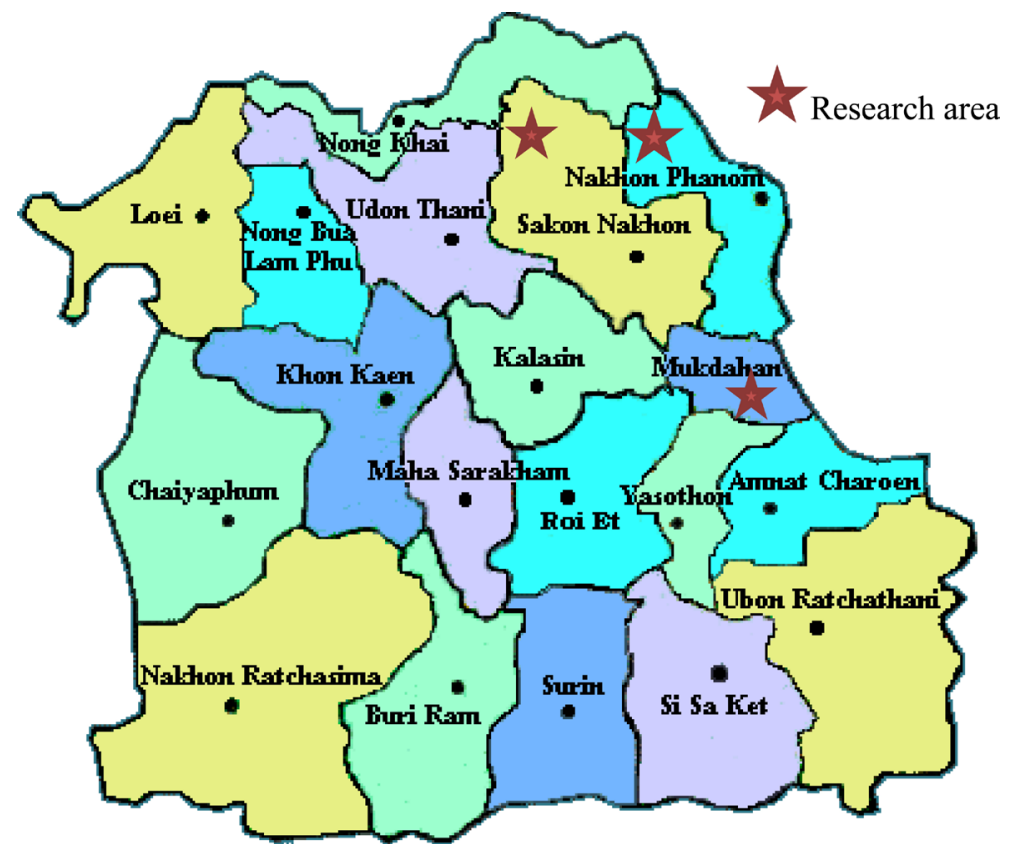

Source: Trekthailand (2012) [18].

Figure 3. Research area in Sakon Nakhon, Nakon Phanom, Mukdahan province in Thailand. 
tourism is needed as an alternative tourism that can benefit the local community in this area.

The article is organized as follows in five sections including an introduction to the volunteer tourism concept and the objectives of the study, the background of the study including a literature review and research framework with the methodology of the study, results, conclusion and future research.

\section{Background of the Study}

\subsection{Factors Affecting the Demand of Volunteer Tourism}

There are several factors that affect the demand of volunteer tourism which are related to volunteer tourism activities that volunteer tourists are able to do during their travels which must be understood. These include community welfare, teaching, business development, environmental regeneration, building projects, cultural development, environment protection and other/miscellaneous journalism [1] [16]. The demand of volunteer tourism is involved with motivation, attitude, needs and the expectation of volunteer tourists [5] as summarized in Table 1 .

\subsection{Research Framework}

The research framework (Figure 4) designed for this study included four variables for developing a factor analysis of volunteer tourism including: attitude (atti), motivation (moti), needs, (need) and expectation (expect).

\section{Methodology}

This research was conducted using a quantitative method and was undertaken in 2016 in a developing country case study in 3 provinces (Sakon Nakhon, Nakon Phanom, Mukdahan) in the Northeast of Thailand. The population was $1,391,460$ tourist which had participated in volunteer tourism activities in the

Table 1. Literatures related to the variables of the study.

\begin{tabular}{lcc}
\hline \multicolumn{1}{c}{ Variable } & Category & Author \\
\hline 1. Attitude & & \\
Goodwill & Increase self-worth & Bruyere and Rappe, 2007 [19], Lepp, 2008 [20] \\
2. Motivation & & \\
Utilitarian & Education & Wearing, 2001 [2], Broad and Jenkins, 2009 [21] \\
Social & Meeting minded people & Bruyere and Rappe, 2007 [19], Mustones, 2007 [22] \\
Purposive & Altruism & Wearing, 2001 [2], Callanan and Tomas, 2005 [1] \\
$\begin{array}{l}\text { 3. Needs } \\
\text { Wanted }\end{array}$ & Adventure/Challenge & Tomazos and Butler, 2009 [23] \\
4. Expectation & & \\
Experience & Wanderlust & Tomazos and Butler, 2009 [23], Brown and Lehto (2005) [24] \\
\hline
\end{tabular}




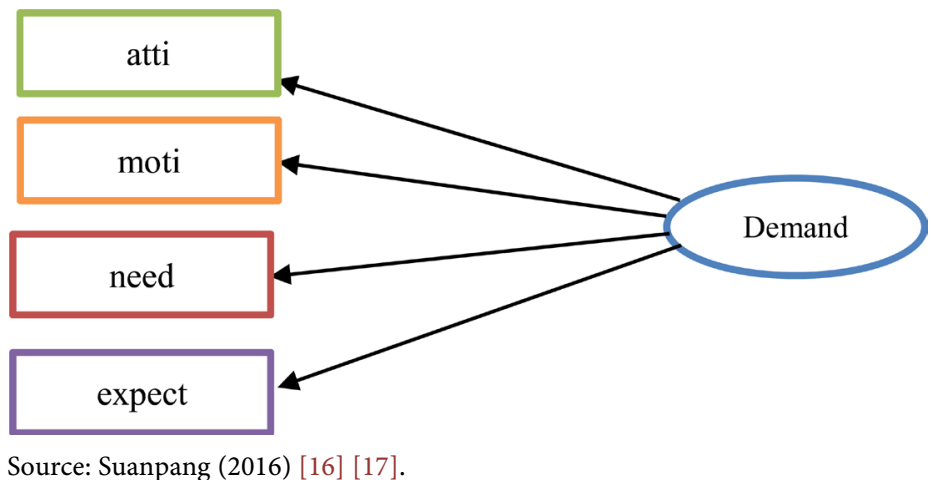

Figure 4. Research framework.

research areas [25]. The sample size was 400 respondents based on Taro Yamane [26] with a confidence level of $95 \%(\alpha=0.05)$. The simple random technique used in this study. The questionnaires were tried out and the Conbach Alpha coefficient was 0.883 .

The questionnaire comprised of 47 questions, of which six related to the demographic of the sample, attitude toward volunteer tourism 8 questions, motivation 9 questions, the expectation of volunteer tourism 7 questions with those using the Likert 5 scale ranging from $5=$ strongly agree, $4=$ agree, $3=$ moderate, $2=$ disagree, 1 = strongly disagree. Data was analyzed using SPSS for descriptive statistic and using Lisrel for factor analysis.

\section{Findings}

\subsection{Demographic of the Volunteer Tourists}

The demographic of the volunteer tourists in Table 2, found that most of the volunteer tourist were male (68\%), aged between 51 - 60 years (24\%), an educational level of a bachelor degree (57\%), occupation of a government officer (37.50\%) and income of between 10,001 - 20,000 baht/month respectively.

\subsection{The Factory Analysis the Demand of Volunteer Tourist}

The factor analysis of the demand of volunteer tourist in Table 3 found that the relationship of the variables attitude (atti) is related with motivation (moti) ( $\mathrm{v}=$ $0.729)$, need (need) is related with attitude (atti) $(\mathrm{v}=.028)$ and motivation (moti) $(\mathrm{v}=0.021)$, and expectation (expect) are related with expectation (expect) $(\mathrm{v}=$ $0.645)$, expectation (expect) $(\mathrm{v}=0.638)$ and need (need) $(\mathrm{v}=0.268)$ respectively.

The factor analysis model of the demand of volunteer tourism is shown in Figure 5 which identifies that Chi-Square $=5.32, \mathrm{df}=2, \mathrm{p}$-vale $=0.06978$, RMSEA $=0.069$. The factor that affected demand the highest was motivation (moti) loading factor $(\mathrm{l})(\mathrm{l}=0.64)$, second, attitude (atti) $(\mathrm{l}=0.56)$, third expectation (expect) $(l=0.49)$ and finally need (need) $(l=0.32)$ respectively.

The results of the confirmatory factory analysis in Table 4 found that motivation (moti) is the highest confirmatory factory analysis $(b=0.644)$, second attitude (atti) $(b=0.557)$, third expectation (expect) $(b=0.492)$ and finally need 
Table 2. Demographic of the respondents.

\begin{tabular}{|c|c|c|}
\hline \multirow{2}{*}{ Variable } & \multicolumn{2}{|c|}{ Values } \\
\hline & Frequency & Percent \\
\hline \multicolumn{3}{|l|}{ Gender } \\
\hline Female & 128 & 32.00 \\
\hline Male & 272 & 68.00 \\
\hline \multicolumn{3}{|l|}{ Age } \\
\hline$>20$ year & 35 & 8.75 \\
\hline $20-30$ year & 64 & 16.00 \\
\hline $31-40$ year & 69 & 17.25 \\
\hline $41-50$ year & 62 & 15.50 \\
\hline $51-60$ year & 96 & 24.00 \\
\hline$<60$ years & 74 & 18.50 \\
\hline \multicolumn{3}{|l|}{ Education level } \\
\hline Under graduate & 114 & 28.50 \\
\hline Bachelor's degree & 228 & 57.00 \\
\hline Master's degree & 50 & 12.50 \\
\hline Ph.D. & 8 & 2.00 \\
\hline \multicolumn{3}{|l|}{ Occupation } \\
\hline Government officer & 150 & 37.50 \\
\hline Business owner & 108 & 27.00 \\
\hline Agriculture & 17 & 4.25 \\
\hline Private sector employee & 43 & 10.75 \\
\hline Student & 38 & 9.50 \\
\hline Other & 44 & 11.00 \\
\hline \multicolumn{3}{|l|}{ Income/month } \\
\hline$>10,000$ bath & 76 & 19.00 \\
\hline $10,001-20,000$ bath & 118 & 29.50 \\
\hline $20,001-30,000$ bath & 44 & 11.00 \\
\hline $30,001-40,000$ bath & 46 & 11.50 \\
\hline $40,001-50,000$ bath & 52 & 13.00 \\
\hline$<50,000$ bath & 64 & 16.00 \\
\hline
\end{tabular}

Table 3. Relationship of the variables.

\begin{tabular}{ccccc}
\hline \multirow{2}{*}{ Variable } & \multicolumn{4}{c}{ Variable } \\
\cline { 2 - 5 } & Attitude & Motivation & Need & Expectation \\
\hline Attitude & 1 & & & \\
Motivation & $0.729^{* *}$ & 1 & 1 & \\
Need & $0.208^{* *}$ & $0.201^{* *}$ & $0.268^{* *}$ & 1 \\
Expectation & $0.645^{* *}$ & $0.638^{* *}$ & & \\
\hline
\end{tabular}

${ }^{* *}$-value $<0.01$. 


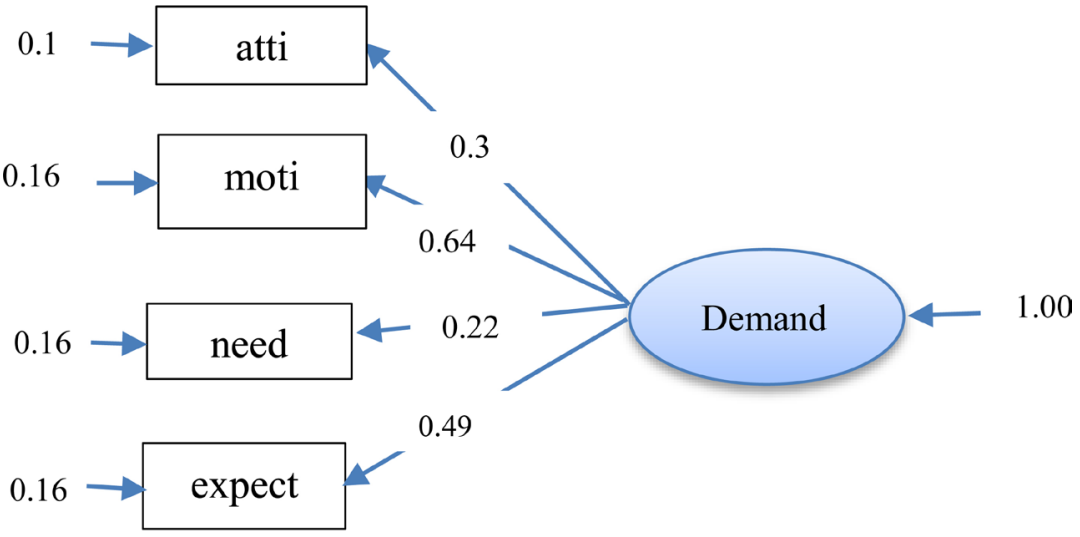

Chi-Square $=5.32, \mathrm{df}=2, \mathrm{P}$-value $=0.06978, \mathrm{RMSEA}=0.069$

Source: Suanpang (2016) [16] [17].

Figure 5. The factor analysis model of demand volunteer tourism.

Table 4. The confirmatory factor analysis results.

\begin{tabular}{ccccc}
\hline \multirow{2}{*}{ Variable } & \multicolumn{3}{c}{ Value } \\
\cline { 2 - 5 } & $\mathrm{b}$ & $\mathrm{SE}$ & $\mathrm{t}$ & $\mathrm{R}^{2}$ \\
\hline Attitude & $0.557^{* *}$ & 0.030 & 18.416 & 0.734 \\
Motivation & $0.644^{* *}$ & 0.035 & 18.142 & 0.717 \\
Need & $0.319^{* *}$ & 0.068 & 4.681 & 0.069 \\
Expectation & $0.492^{* *}$ & 0.031 & 15.704 & 0.573
\end{tabular}

$\chi^{2}=5.32, \mathrm{df}=2, \mathrm{p}$-value 0.06, $\mathrm{GFI}=0.99, \mathrm{AGFI}=0.96, \mathrm{CFI}=0.99, \mathrm{NNFI}=0.99, \mathrm{RMSEA}=0.07$, $\mathrm{SRMR}=0.02, \mathrm{RMR}=0.02$

${ }^{* *}$ - -value $<0.01$.

Table 5. Statistical significance of the goodness of fit indices.

\begin{tabular}{cccc}
\hline \multirow{2}{*}{ Statistic } & & Value & \\
\cline { 2 - 4 } & Criteria & Value & result \\
\hline$\chi^{2}$ & $<2.00$ & 2.16 & Non-pass \\
p-value & $>0.05$ & 0.06 & pass \\
GFI & $>0.95$ & 0.99 & pass \\
AGFI & $>0.95$ & 0.96 & pass \\
CFI & $>0.95$ & 0.99 & pass \\
NNFI & $>0.95$ & 0.98 & pass \\
NFI & $>0.95$ & 0.99 & pass \\
RMR & $<0.05$ & 0.02 & pass \\
SRMR & $<0.05$ & 0.02 & pass \\
\hline
\end{tabular}

(need) $(b=0.319)$. Therefore, the values of the demand of volunteer tourism in the Sanuk group (Sakon Nakhon, Nakon Phanom, Mukdahan provinces) in Thailand were $71 \%, 73.40 \%$ and $57.30 \%$ respectively. 
The statistical significance of the fit indices in Table 5 , found that every variable passed the criteria [27] except $\chi^{2} / \mathrm{df}$. Therefore, the variable factor attitude (atti), motivation (moti), need (need) and expectation (expect) were goodness of fit test for the demand of volunteer tourism in a developing country case study in Thailand.

\section{Conclusions and Future Work}

Volunteer tourism is becoming widespread because it brings a new tourism experience from "reviver" to become "giver" that tourist can spend time during their travels to help a community to become a better place to life. This created a valuable experience in the heart and soul of the tourist. Volunteer tourism is intensifying in Thailand, which is a developing country [28] [29].

This paper studies the demand of volunteer tourism in a developing country case study in the Northeast of Thailand. The result found that, the most important factor was the "motivation" $(1=0.644)$ of tourists, second "attitude toward" $(l=0.557)$ volunteering, third "expectation" $(l=0.492)$ and finally "need" $(l=$ 0.319 ) for helping people. Therefore, the variation of the demand of volunteer tourism was $71 \%, 73.40 \%$ and $57.30 \%$ respectively. By the statistical significance of the goodness of fit indices, the results found that every variable passed the criteria

The suggestion is that volunteer projects in developing countries should build motivating activities for volunteers that give knowledge back [18], should initiate attitude toward joining volunteer projects and finally should develop more experience for the tourists to help the local community to become a better place to living.

Future research should study the factors that affect the decision making of the volunteer tourist to join volunteer tourism projects in developing countries in ASEAN such as in Laos and Cambodia.

\section{Acknowledgements}

The author would like to acknowledge The Thailand Research Fund (TRF) which provided the budget to conduct this research (RDG 5750008). Also would like to acknowledge Suan Dusit University which provided the resources for helping Panphu Primary School at Mukdahan provinces.

\section{References}

[1] Callanan, M. and Thomas, S. (2005) Niche Tourism: Contemporary Issue, Trends and Case. Taylor \& Francis, UK, 183-200.

[2] Wearing, S. (2001) Volunteer Tourism: Experiences That Make a Different. CABI, Oxon. https://doi.org/10.1079/9780851995335.0000

[3] Butcher, J. (2011) Volunteer Tourism May Not Be as Good as It Seems. Tourism Recreation Research, 36, 75-76. https://doi.org/10.1080/02508281.2011.11081662

[4] Stainton, H. (2016) A Segmented Volunteer Tourism Industry. Annals of Tourism Research, 61, 256-257. https://doi.org/10.1016/j.annals.2016.09.011 
[5] Tomazos, K. and Butler, R. (2012) Volunteer Tourists in the Field: A Question of Balance? Tourism Management, 33, 177-187. https://doi.org/10.1016/j.tourman.2011.02.020

[6] Singh, S. and Singh, T.V. (2001) Pilgrimages to the Himalayas. New Horizons in Tourism: Strange Experience and Stranger Practices. CABI, London.

[7] Singh, T.V. (2004) New Horizons in Tourism: Strange Experiences and Stranger Practices. CABI, London. https://doi.org/10.1079/9780851998633.0000

[8] Suvantola, J. (2002) Tourist's Experience of Place. Ashgate, Hants.

[9] Batcher, J. (2003) The Moralisation of Tourism Sun, Sand... and Saving the World? Routledge, London.

[10] Stebbins, R.A. (1992) Amateurs Professional and Serious Leisure. McGill-Queens University Press, Ulster.

[11] Tourism Research \& Marketing (2008) Volunteer Tourism: A Global Analysis. A Report by Tourism Research and Marketing. Association for Tourism and Leisure Education, Barcelona.

[12] Wearing, S. and McGehee, N.G. (2013) Volunteer Tourism: A Review. Tourism Management, 38, 120-130. https://doi.org/10.1016/j.tourman.2013.03.002

[13] Earthwatch Institute Website (2017). http://www.earthwatch.org/earthwatch_fact_sheet

[14] Voluntorism.org. (2008) Voluntourism. http://www.voluntourism.org/

[15] Kontogeorgopoulos, N. (2017) Finding Oneself While Discovering Others: An Existential Perspective on Volunteer Tourism in Thailand. Annals of Tourism Research, 65, 1-12. https://doi.org/10.1016/j.annals.2017.04.006

[16] Santijanyaporn, J., Suanpang, P., Sopha, C. and Kansarnsanti, K. (2016) The Study of Voluntourism Demand and Supply in Sanuk Group (Sakon Nakhon, Nakon Phanom, Mukdahan) Thailand. Thailand Research Fund (TRF), Bangkok.

[17] Suanpang, P. (2016) The Voluntourism Development in Sanuk Group (Sakon Nakhon, Nakon Phanom, Mukdahan) Thailand. Thailand Research Fund (TRF), Bangkok.

[18] Trekthailand (2012) Photo Essays of Thailand Travel. http://www.trekthailand.net/p2/

[19] Bruyere, B. and Rapped, S. (2007) Identifying the Motivations of Environmental Volunteers. Journal of Environmental Planning and Management, 50, 503-516. https://doi.org/10.1080/09640560701402034

[20] Lepp, A. (2008) Discovering Self and Discovering Others through the Taita Discovery Centre Volunteer Tourism Program, Kenya. In: Lyons, K.D. and Wearing, S., Eds., Journeys of Discovery in Volunteer Tourism: International Case Study Perspectives, CABI, Wallingford, 86-100.

[21] Broad, S. and Jenkins, J. (2009) Gibbons in Their Midst? Conservation Volunteer's Motivations at the Gibbon Rehabilitation Project in Phuket Thailand. In: Lyons, K.D. and Wearning, S., Eds., Journeys of Discovery in Volunteer Tourism, CABI, Wallingford, 72.

[22] Mustonen, P. (2007) Volunteer Tourism-Altruism or More Tourism? Anatolia: An International Journal of Tourism and Hospitality Research, 18, 97-115.

[23] Tomazos, K. and Butler, R.W. (2009) Volunteer Tourism: The New Ecotourism? Anatolia: An International Journal of Tourism and Hospitality Research, 1, 196-212. 
[24] Brown, S. and Lehto, X. (2005) Travelling with a Purpose: Understanding the Motives and Benefits of Volunteer Vacationers. Current Issues in Tourism, 8, 476-496. https://doi.org/10.1080/13683500508668232

[25] Department of Tourism (2015) Statistics of Tourist. http://www.tourism.go.th Trekthailand (2012) Thailand North-Eastern Provinces. http://www.trekthailand.net/p2/

[26] Yamane, T. (1973) An Introductory Analysis. 3rd Edition, Harper and Row Publication, New York.

[27] Schumacker, R.E. and Lomax, R.G. (2010) A Beginners Guide to Structural Equation Modeling. Routledge, New York.

[28] Santijanyaporn, J., Suanpang, P., Sopha, C. and Kankarensanti, V. (2016) The Study of Voluntourism Demand and Supply in Sanuk Group (Sakon Nakhon, Nakhon Phanom, Mukdahan). Thailand Research Fund (TRF), Bangkok.

[29] Zarandian, N., Shalbafian, A., Ryan, C. and Bidokhti, A. (2016) Islamic Pro-Poor and Volunteer Tourism-The Impacts on Tourist: A Case Study of Shabake Talayedarn Jihad, Teheran-A Research Note. Tourism Management Perspective, 19, 165-169. https://doi.org/10.1016/j.tmp.2015.12.005 